\title{
Neurotransmitter Receptors in Fetal Tissue Transplants: Expression and Functional Significance
}

\author{
Sunny Y. $\mathrm{Lu}^{1}$ and Andrew B. Norman ${ }^{1,2,3}$ \\ Division of Neuroscience, Departments of ${ }^{1}$ Psychiatry, ${ }^{2}$ Anatomy and ${ }^{3}$ Physiology \\ University of Cincinnati College of Medicine, Cincinnati, Ohio 45267-0559, USA
}

\begin{abstract}
Numerous studies have examined receptor expression in neural transplants and their possible role in transplant-induced functional recovery from lesion-induced deficits. Herein we attempt to summarize the results of these studies, especially those from studies involving striatal transplants. Autoradiographic studies indicate that dopamine $D_{1}$ and $D_{2}$, muscarinic, cholinergic, 5-HT ${ }_{2}$, opiate $\mu, \beta$ adrenergic and cholecystokinin (CCK) receptors are present in striatal transplants. Many of these receptors are present regardless of the transplant location and surrounding environment. This suggests that the expression of these receptors is determined by intrinsic properties of transplanted tissue, and is independent of transplant location and environment. Some transplant receptors, such as dopamine $D_{1}$ and $D_{2}$ and muscarinic receptors in striatal transplants, or $5-\mathrm{HT}_{2}$ receptors in cortical transplants, display a patchy distribution which is dissimilar to that in the corresponding adult host tissue. This manuscript discusses this "abnormal" receptor distribution and possible explanations. Electrophysiological studies have indicated that some of the transplant receptors respond to physiological and pharmacological stimulation, suggesting that they are functional. However, the association of receptor expression with behavioral recovery is uncertain. The expression of neurotransmitter receptors in neural transplants may not be essential for the
\end{abstract}

Reprint address:

Dr. Andrew B. Norman

Department of Psychiatry

University of Cincinnati

College of Medicine

Cincinnati, OH 45267-0559, USA functional recovery associated with trophic mechanisms. However, neurotransmitter receptors may play an important role when functional recovery requires neuroanatomical integration between the host brain and the transplanted tissue.

\section{KEY WORDS}

dopamine, serotonin, behavior, muscarinic acetylcholine receptors, fetal tissue grafts, $c$-fos

\section{INTRODUCTION}

Numerous studies have demonstrated that fetal brain tissues can survive transplantation and develop some neuroanatomical and histochemical features characteristic of mature tissues $/ 7,22,28 /$. Neural transplants can also ameliorate many behavioral abnormalities induced by neurotoxic lesions in animal models of Parkinson's disease and Huntingon's disease $/ 2,16,17,18,27,42,49,51,55 /$. For example, transplants of fetal striatal tissue into excitotoxin-lesioned striatum have been shown to ameliorate the striatal lesion-induced abnormalities in spontaneous behaviors, such as locomotor activity /45,50/ and skilled paw reaching behaviors $/ 16 /$, and also drug-induced deficits, including apomorphine-induced rotational behavior $/ 16,40$, 43/, apomorphine and amphetamine-induced locomotion $/ 11,14,49 /$ and haloperidol-induced catalepsy $/ 19 /$. In addition, striatal transplants have been reported to produce recoveries of lesioninduced neurochemical deficits, such as for choline acetyltransferase (CAT) and gamma-aminobutyric acid (GABA) /28/.

Recent experiments have focused on the possible mechanisms by which neural transplants promote 
behavioral recovery. One hypothesis is functional anatomical integration between transplant and host. Some specific afferent and efferent connections between transplants and host have been reported $12,4,45,63-65 /$. If these anatomical connections are important for transplant-induced recovery, neurotransmitter receptors will be required to mediate these effects, since they are necessary for synaptic signal transduction.

Several groups have studied receptor expression and possible function in fetal striatal tissue transplants $/ 13,14,24,28,35,38,40,43,62 /$. Herein we attempt to summarize the findings in this area and discuss the development of receptors in transplants and their possible role in transplant functions.

\section{RECEPTOR EXPRESSION IN NEURAL TRANSPLANTS}

Several groups have demonstrated that fetal striatal tissue can survive and express a variety of receptors and transmitter specific neuronal markers. The biochemical markers for intrinsic neurons identified in striatal transplants include acetylcholinesterase (AChE) 122,28,50,59/, met-enkephalin (met-ENK), substance P (SP), somatostatin (SS), cholecystokinin (CCK) and neuropeptide Y (NPY) $122,28 /$.

Autoradiographic studies have demonstrated that dopamine $\mathrm{D}_{1}$ and $\mathrm{D}_{2}$ muscarinic cholinergic, 5$\mathrm{HT}_{2}$, opiate $\mu$ and $\delta$, adrenergic $\beta$ and CCK

TABLE 1

Summary of the expression of neurotransmitter receptors and second messenger systems in fetal striatal tissue transplants

\begin{tabular}{|c|c|c|c|c|c|c|}
\hline study & Donor & Host & $\begin{array}{l}\text { Months } \\
\text { Post- } \\
\text { Graft }\end{array}$ & Ligand/Receptor & Result & $\begin{array}{l}\text { Functional } \\
\text { Correlation }\end{array}$ \\
\hline $\begin{array}{l}\text { Beresford } \\
\text { et al, } \\
\text { (1) }\end{array}$ & $\begin{array}{l}\text { E13-15 } \\
\text { cell } \\
\text { suspen- } \\
\text { sion }\end{array}$ & & & {$\left[{ }^{125} \mathrm{I}\right] \mathrm{CCK}-8 / \mathrm{CCK}$} & $(+)$, patchy & $\begin{array}{l}\text { Reduction of } \\
\text { rotational behavior }\end{array}$ \\
\hline $\begin{array}{l}\text { Deckel } \\
\text { et al, } \\
(11)\end{array}$ & $\begin{array}{l}\text { E17-18 } \\
\text { whole } \\
\text { cell } \\
\text { suspen- } \\
\text { sion }\end{array}$ & $\begin{array}{l}\text { Female } \\
\text { rat with } \\
\text { or } \\
\text { without } \\
\text { KA lesion }\end{array}$ & 6 & $\begin{array}{c}\text { Spiperone } / \mathrm{D}_{2} \\
\text { dopamine }\end{array}$ & $(-)$ & $\begin{array}{l}\text { Receptor density } \\
\text { inversely correlated } \\
\text { with the locomotor } \\
\text { hyperactivity following } \\
\text { amphetamine and } \\
\text { apomorphine }\end{array}$ \\
\hline $\begin{array}{l}\text { Deckel } \\
\text { et al, } \\
(12)\end{array}$ & E18 & $\begin{array}{l}\text { Adult } \\
\text { female } \\
\text { rat with } \\
\text { KA lesion }\end{array}$ & 9 & $\begin{array}{l}{\left[{ }^{125} \Pi \text { cyanopindolol }\right.} \\
+I C I-89406 / \beta_{1} \\
{\left[{ }^{125} \Pi \text { cyanopindolol }\right.} \\
+I C I-118551 / \beta_{2}\end{array}$ & $\begin{array}{l}(+) \\
(+) \text { the same } \\
\text { density as in host } \\
\text { striatum }\end{array}$ & \\
\hline $\begin{array}{l}\text { Deckel } \\
\text { et al, } \\
(13)\end{array}$ & $\begin{array}{l}\text { E17 } \\
\text { cell } \\
\text { suspen- } \\
\text { sion }\end{array}$ & $\begin{array}{l}\text { Adult } \\
\text { female } \\
\text { rat with } \\
\text { KA lesion } \\
\text { or without }\end{array}$ & $\begin{array}{l}8 \\
\mathrm{t}\end{array}$ & $\begin{array}{l}\text { NMS+carbachol } / \mathrm{M}_{1} \\
\mathrm{NMS}+\text { atropine } / \mathrm{M}_{2}\end{array}$ & $\begin{array}{l}(+) \text { reduced } \\
\text { density } \\
(+) \text { increased } \\
\text { density }\end{array}$ & $\begin{array}{l}\text { Receptor density } \\
\text { correlated with the } \\
\text { sensorimotor and } \\
\text { alternation task, but } \\
\text { not correlated with } \\
\text { locomotor measurement, } \\
\text { inversely correlated } \\
\text { with behavior following } \\
\text { amphetamine and apomorphine }\end{array}$ \\
\hline $\begin{array}{l}\text { Deckel } \\
\text { et al, } \\
(14)\end{array}$ & $\begin{array}{l}\text { E19 } \\
\text { cell } \\
\text { suspen- } \\
\text { sion }\end{array}$ & $\begin{array}{l}\text { Adult } \\
\text { female } \\
\text { rat with } \\
\text { KA lesion } \\
\text { or without }\end{array}$ & $\begin{array}{l}6 \\
6\end{array}$ & Spiperone/ $D_{2}$ & $(+)$, patchy & $\begin{array}{l}\text { Receptor density } \\
\text { inversely correlated } \\
\text { with behavior } \\
\text { following amphetamine } \\
\text { and apomorphine injection }\end{array}$ \\
\hline
\end{tabular}


TABLE 1 (cont.)

\begin{tabular}{|c|c|c|c|c|c|c|}
\hline study & Donor & Host & $\begin{array}{l}\text { Months } \\
\text { Post- } \\
\text { Graft }\end{array}$ & Ligand/Receptor & Result & $\begin{array}{l}\text { Functional } \\
\text { Correlation }\end{array}$ \\
\hline \multirow[t]{4}{*}{$\begin{array}{l}\text { Helm } \\
\text { et al, } \\
(24)\end{array}$} & $\begin{array}{l}\text { E15-16 } \\
\text { cell } \\
\text { suspen- } \\
\text { sion }\end{array}$ & $\begin{array}{l}\text { Adult } \\
\text { rats with } \\
\text { KA lesion }\end{array}$ & $4-6 \cdot 5$ & $\begin{array}{l}\mathrm{SCH} 23390 / \mathrm{D}_{1} \\
\text { Spiperone/D } \\
\text { QNB/muscarinic }\end{array}$ & $\begin{array}{l}(+), \text { patchy } \\
(-) \\
(+) \text {, even }\end{array}$ & \\
\hline & & & & $\begin{array}{l}\text { Hemicholinium/ } \\
\text { high affinity } \\
\text { choline uptake } \\
\text { site }\end{array}$ & $(-)$ & \\
\hline & & & & $\begin{array}{l}\text { Forskolin/ } \\
\text { adenylate cyclase }\end{array}$ & $(+)$, patchy & \\
\hline & & & & $\begin{array}{l}\text { Phorbol } 12,13- \\
\text { dibutyrate/ } \\
\text { protein kinase c }\end{array}$ & \multicolumn{2}{|c|}{$\begin{array}{l}(+) \text {, evenly throughout } \\
\text { the graft }\end{array}$} \\
\hline $\begin{array}{l}\text { Isacson } \\
\text { et al, } \\
(28)\end{array}$ & $\begin{array}{l}\text { E14-15 } \\
\text { cell } \\
\text { suspen- } \\
\text { sion }\end{array}$ & & 6 & $\begin{array}{l}\text { Spiperone/D } \\
\text { Diprenorphine/ } \\
\text { opiate }\end{array}$ & $\begin{array}{l}(+), \text { patchy } \\
(+), \text { patchy }\end{array}$ & \\
\hline & & & & PBCM/muscarinic & $(+)$, even & \\
\hline $\begin{array}{l}\text { Lanca } \\
\text { et al, } \\
(33)\end{array}$ & $\begin{array}{l}\text { E12-19 } \\
\text { cell } \\
\text { suspen- } \\
\text { sion }\end{array}$ & $\begin{array}{l}\text { Rat pups } \\
\text { and } \\
\text { young } \\
\text { adult }\end{array}$ & $1-3$ & $\begin{array}{l}\text { Etorphine/opiate } \\
\text { Spiperone/ } \mathrm{D}_{2}\end{array}$ & $\begin{array}{l}(+), \text { patchy } \\
(-)\end{array}$ & \\
\hline $\begin{array}{l}\text { Lu } \\
\text { et al, } \\
(36)\end{array}$ & $\begin{array}{l}\text { E15-17 } \\
\text { solid } \\
\text { tissue }\end{array}$ & $\begin{array}{l}\text { Adult } \\
\text { male rat } \\
\text { with } \\
\text { intact } \\
\text { striatum }\end{array}$ & $1.5-15$ & $\begin{array}{l}\mathrm{SCH} 23390 / \mathrm{D}_{1} \\
\text { Spiperone/D } \\
\text { Ketanserin/5-HT } \\
\text { QNB/muscarinic }\end{array}$ & $\begin{array}{l}(+), \text { patchy } \\
(+), \text { patchy } \\
(+) \text {, patchy } \\
(+) \text {, even }\end{array}$ & \\
\hline $\begin{array}{l}\text { Mayer } \\
\text { et al, } \\
(38)\end{array}$ & $\begin{array}{l}\text { E15 } \\
\text { cell } \\
\text { suspen- } \\
\text { sion }\end{array}$ & $\begin{array}{l}\text { Adult } \\
\text { female } \\
\text { rat with } \\
\text { ibotenic } \\
\text { acid } \\
\text { lesion }\end{array}$ & 3 & $\begin{array}{l}S C H 23982 / D_{1} \\
\text { sulpiride } / D_{2}\end{array}$ & $\begin{array}{l}(+), \text { patchy } \\
(+) \text {, patchy }\end{array}$ & \\
\hline $\begin{array}{l}\text { Norman } \\
\text { et al, } \\
(43)\end{array}$ & $\begin{array}{l}\text { E17 } \\
\text { solid } \\
\text { tissue }\end{array}$ & $\begin{array}{l}\text { Male } \\
\text { adult } \\
\text { rats with } \\
\text { KA lesion }\end{array}$ & 2.5 & $\begin{array}{l}S C H 23390 / D_{1} \\
\text { Spiperone/D } \\
\text { Forskolin / } \\
\text { adenylate cyclase }\end{array}$ & $\begin{array}{l}(-) \\
(-) \\
(-)\end{array}$ & $\begin{array}{l}\text { No correlation with } \\
\text { the recovery of the } \\
\text { lesion-induced } \\
\text { rotational behavior }\end{array}$ \\
\hline
\end{tabular}

"(+)" -- indicates the presence of receptors in the transplants

"(-)" -- indicates the absence of receptors in the transplants

NMS $=$ N-Methylscopolamine

$\mathrm{PBCM}=$ Propylbenzilylcholine mustard 
receptors are present in striatal transplants $/ 1,11,12$, $13,14,24,28,33,36,38$ / (results are summarized in Table 1). These receptors are normally present in adult rat striatum $/ 21 /$. The density of $D_{1}$ dopamine receptors in striatal transplants was reportedly about 2 to 3-fold higher than that of dopamine $D_{2}$ receptors $/ 38 /$, which is similar to that in normal striatum. The dopamine $D_{1}$ and $D_{2}$ and muscarinic receptors were present in striatal transplants as early as 6 weeks after transplantation $/ 36 /$. In most reports, the receptors were observed in striatal transplants about 3-11 months after the implantation (see Table 1).

However, the autoradiographic studies have also shown some conflicting findings. Deckel et al. /11/ initially reported the absence of dopamine $D_{2}$ receptors in striatal transplants. Similarly, Norman et al. /43/ reported an apparent lack of $D_{1}$ and $D_{2}$ dopamine receptors within the transplant. However, subsequent studies $/ 36 /$, using transplants into nonlesioned adult rat brain, reported the patchy distribution of dopamine $D_{1}$ and $D_{2}$ receptors, muscarinic receptors and the presence of $5-\mathrm{HT}_{2}$ receptors in the striatal transplants. A recent study by Helm et al. 124/ reported the absence of dopamine $\mathrm{D}_{2}$ receptors in 4 and 6.5 month-old transplants, which was consistent with the studies of Norman et al. /43/ and Deckel et al. /11/. Dopamine $D_{1}$ receptors were also found to be absent at 4 months, consistent with the results of Norman et al. $143 /$, but were reported to be present in sparse patches at 6 months post transplant /24/.

When neurotransmitter receptors are found to be expressed in transplanted fetal tissue the distribution is often patchy. Less clear is the reason for the apparent lack of or inconsistent receptor expression in some studies. This relative lack of receptors in transplants cannot be due to technical problems with the autoradiographic assay procedure as binding of the radioligand to appropriate receptors in adjacent host tissues is apparent. Furthermore, this inconsistency is not due to the different forms of embryonic tissue transplanted, such as cell suspension vs. tissue block, because in either case, both positive and negative results have been reported. Additionally, differences in receptor expression between studies are apparent even from the same laboratories. Deckel et al., although initially reporting a lack of $D_{2}$ dopamine receptors, subsequently observed $D_{2}$ dopamine receptors $/ 14 /$. A lack of $D_{1}$ and $D_{2}$ receptors was observed in some studies /43/ but subsequent studies using a similar protocol of striatal transplants into nonlesioned adult rat brain observed the patchy distribution of both $\mathrm{D}_{1}$ and $\mathrm{D}_{2}$ dopamine receptors /36/.

\section{EXPRESSION OF TRANSPLANT INTRINSIC RECEPTORS MAY BE INDEPENDENT OF TRANSPLANT LOCATION AND ENVIRONMENT}

Normal striatum has relatively high levels of dopamine $D_{1}$ and $D_{2}$ and muscarinic acetylcholine receptors, high to moderate levels of adrenergic $\alpha$ and $\beta, 5-\mathrm{HT}$ and opiate receptors $/ 9,21 /$. Expression of receptors in neurons during normal development may depend on genetic information. Additionally, environmental cues, such as target innervation, hormonal levels, etc., may also play an important role. Studies on the expression of neurotransmitter receptors in transplants placed in different locations within the brain or into the anterior chamber of the eye, provide information which may reflect the influence of the local environment. For instance, when striatal transplants were placed either into striatum (homotopic location) or globus pallidus or substantia nigra (ectopic locations), dopamine $D_{2}$, muscarinic and opiate receptors, in addition to the neurochemical markers AChE, SP, met-ENK and NPY, were expressed in the tissues placed in all locations. In addition, the distribution, uniform in the case of muscarinic receptors and patchy in the case of the other receptors and the neurochemical markers, was independent of the location of the transplant /28/. Even when striatal transplants were placed in the lateral ventricle in which the transplants were relatively isolated from anatomical interactions, they were able to express $D_{1}$ and $D_{2}$ dopamine and muscarinic receptors $/ 36,38 /$. Similarly, many types of transplants can develop appropriate neuronal neurochemical markers and receptors when they are transplanted into the anterior chamber of the eye /44/. In addition, fetal striatal transplants expressed the same types of receptors when they were placed either in excitotoxin lesioned striatum or intact striatum $/ 13,14,28,36 /$. 
Neurotransmitter receptors have also been identified in other types of transplants, for example, $\alpha$ and $\beta$ adrenergic receptors in intraocular cerebellar transplants $/ 20 /, \beta$ adrenergic receptors in fetal cortical and cerebellar tissues transplanted into cortex $/ 34 /$, muscarinic and $5-\mathrm{HT}_{2}$ receptors in ventral mesencephalic and cortical tissues transplanted into striatum $/ 36 /$. Therefore, these data suggest that the expression of appropriate receptors and of some phenotypic neurochemical markers in transplants is largely determined by intrinsic environmental or genetic information rather than extrinsic environmental factors.

However, this may not be true for certain receptors which may depend on extrinsic conditions, such as anatomical connections from the host, for their expression and normal development. The expression of opiate $\mu$ receptors in homotopic striatal transplants has been reported to require innervation by host dopaminergic fibers /54/. Opiate $\mu$ receptors have been reported to be located on dopaminergic terminals originating from the substantia nigra /54/. Therefore, this receptor maybe extrinsic to striatal tissue and its expression within intrastriatal transplants may reflect the ingrowth of dopaminergic terminals from the host.

\section{THE DISTRIBUTION OF RECEPTORS WITHIN TRANSPLANTS IS DISSIMILAR TO THAT IN HOST}

Despite the presence of receptors with densities sometimes similar to those observed in the host, the distribution of receptors in transplants is clearly different from that in the adult host. Some receptors are found in very discrete areas within the transplant often in relatively high densities, while in other areas of the transplant the receptors are often absent. This patchy receptor distribution characterizes dopamine $D_{1}$ and $D_{2}$, and opiate $\mu$ receptors in striatal transplants $/ 14,28,36,38,62 /$. The distribution of muscarinic receptors has been described as patchy or non-uniform in some studies /13,36/ but more uniform in other studies $/ 28 / .5-\mathrm{HT}_{2}$ receptors have been reported to be evenly distributed throughout striatal transplants but patchy in cortical transplants $136 /$. The patchiness of the distribution of $D_{1}$ and $D_{2}$ dopamine and muscarinic receptors in fetal striatal transplants as well as the opiate $\mu$ receptor is dissimilar to that in the host striatum. These patches of relatively high receptor density have been reported to correspond to the patches in the striatal transplants that are rich in $\mathrm{AChE}$, met-ENK, substance $\mathrm{P}$, somatostatin and tyrosine hydroxylase $128,66 /$. It was initially suggested that this patchy distribution of receptors and neurochemical markers may reflect the compartmentation known as striosomes normally present during development and in mature striatum /28,33/. However, Graybiel et al. $/ 22 /$ suggested that these high density patches rich in a variety of the neurochemical markers may have achieved a phenotype resembling normal developing and mature striatum while the histochemical features of the low density patches were similar to immature striatum and non-striatal tissues. The possibility was suggested that some globus pallidus, basolateral amygdala and cortical tissue was included during the dissection of fetal striatum due to the proximity of these tissues to the dissection area $/ 22,28 /$.

The purity of transplanted fetal tissues can be more easily maintained using fetal cortex as this tissue is relatively large and clearly differentiated from other areas of the fetal brain. In cortical transplants clear lamination of $5-\mathrm{HT}_{2}$ receptors which was observed in the host cortex was not seen. Instead, dispersed patches of 5- $\mathrm{HT}_{2}$ receptors having relatively high density were intermingled with low density areas $/ 36 /$. From the corresponding Nissl stained sections it was evident that this patchiness of receptor density was not due to uneven density of neurons within the transplant. Furthermore, the muscarinic receptors in the same transplant were evenly distributed. It is, therefore, possible that the high density patches of $5-\mathrm{HT}_{2}$ receptors were caused by clustering of the cortical neurons that express high densities of $5-\mathrm{HT}_{2}$ receptors. These high density patches may have intermingled with cortical neurons expressing low densities of $5-\mathrm{HT}_{2}$ receptors, which in some degree resembled the normal cortex, but with a disrupted laminar organization. Alternatively, it is possible that the neurons in the high receptor density regions received a signal which stimulated the expression of $5-\mathrm{HT}_{2}$ receptors while the neurons in the low receptor density region did not receive such a signal. However, there have been no systematic 
studies to evaluate these hypotheses. These data suggest that the patchy distribution of some neurotransmitter receptors, at least within cortical transplants, is not due to the impurity of the transplanted fetal tissue. Rather, although some phenotypes of mature tissues can be expressed in transplanted tissue, certain essential elements required for complete normal organization of cells or the development of receptors and other neurochemical markers within the transplanted tissue may have been missing or inadequate.

\section{PHYSIOLOGICAL FUNCTION OF RECEPTORS IN TRANSPLANTS}

The physiological function of receptors in striatal transplants has also been studied. Wichmann and Starke $/ 62 /$ have studied the effect of striatal transplant-derived dopamine receptors and muscarinic and opiate receptors on acetylcholine release from transplants by measuring $\left[{ }^{3} \mathrm{H}\right]$ acetylcholine efflux from slices of transplanted striatum. They reported that the activation of dopamine $\mathrm{D}_{2}$, muscarinic and opiate $\delta$ receptors by specific receptor agonists inhibited $\left[{ }^{3} \mathrm{H}\right]$ acetylcholine release from slices of transplanted striatum which resembled the effect in normal striatum. This effect increased with increasing concentration of the agonists, and was abolished by appropriate receptor antagonists. The results indicated that these receptors had similar functions to the corresponding receptors in normal striatum with regard to modulation of acetylcholine release. In addition, electrophysiological recording has revealed that the synapses formed between transplant and host can be functional. The response observed in transplants by stimulation of the host neurons $/ 2,25,48,61 /$ is presumably mediated by neurotransmitters from the stimulated host neurons acting on neurotransmitter receptors present on the transplanted neurons. Further evidence of functional receptors mediating physiological activities comes from studies showing that $\alpha$ and $\beta$ adrenergic receptors in intraocular cerebellar transplants mediated the electrophysiological effect of norepinephrine on Purkinje neurons $/ 20$. Furthermore, data from intracerebral dialysis from intrastriatal nigral transplants indicated that dopamine autoreceptors in nigral tranplants may mediate the autoregulation of dopamine release and metabolism $/ 57 /$. A methamphetamine-induced stimulation of GABA release in the globus pallidus and substantia nigra was also restored by striatal tissue grafts into excitotoxin-lesioned striatum /54/, suggesting that functional dopaminergic modulation within the transplanted tissue of GABA output neurons was re-established. These dopamine receptors within both nigral and striatal transplants may develop functions similar to those in mature tissue.

In normal brain, some neurotransmitter receptors are associated with the second messenger system, adenylate cyclase $156 /$. Therefore, the presence of second messenger systems in transplanted tissues may be an indicator of functional receptors. $\left[{ }^{3} \mathrm{H}\right]$ Forskolin binding has been used to identify the stimulatory guanine nucleotide regulatory subunit/adenylate cyclase complex and its association with the $\mathrm{D}_{1}$ dopamine receptors in transplants $/ 24,43 /$. Norman et al. $/ 43 /$ demonstrated a relative deficit of $\left[{ }^{3} \mathrm{H}\right]$ forskolin binding sites corresponding to the lack of $D_{1}$ dopamine receptors in the striatal transplants at 12 weeks post transplant. A recent study by Helm et al. $124 /$ reported the presence of a patchy distribution of $\left[{ }^{3} \mathrm{H}\right]$ forskolin binding sites in 6 month-old transplants which was similar to the $D_{1}$ dopamine receptor patches in the striatal transplant, again suggesting their possible association. $\left[{ }^{3} \mathrm{H}\right]$ Phorbol ester binding to protein kinase $\mathrm{C}$, another second messenger system, was present in the transplanted striatal tissue, but in contrast to the dispersed patches of $\left[{ }^{3} \mathrm{H}\right]$ forskolin binding, protein kinase $\mathrm{C}$ was very prominent throughout the transplant $/ 24 /$. The available data suggest that $D_{1}$ dopamine receptors when present in striatal transplants are associated with the presence of adenylate cyclase and protein kinase $\mathrm{C}$, though not necessarily in a normal stoichiometric relationship. However, there are no studies to date to determine whether receptor agonists elicit activation of second messenger systems within transplants. Such studies would be technically difficult. However, indirect evidence might come from the measurement of the expression of immediate-early response gene products $/ 15 /$. The expression of such proto- 
oncogenes, for example $c$-fos, can be stimulated by a number of neurotransmitters and receptor agonists. For example, D-amphetamine or cocaine elicits a marked expression of $c$-fos in rat striatum through indirect activation of dopamine receptors, especially of the $D_{1}$ subtype $/ 23,47 /$. Therefore, the amphetamine-induced activation of $c-f o s$ in fetal tissue transplants might indicate the presence of functional monoaminergic synapses in the transplanted tissues. In cortical and striatal tissues transplanted into rat striatum most of the dopaminergic innervation would be from the host. The expression of $c$-fos in the transplants could be indicative of functional $D_{1}$ dopamine receptors on the transplanted neurons. Amphetamine was able to stimulate the expression of fos-like immunoreactivity in fetal striatal grafts transplanted into intact adult striatum $/ 37 /$. This amphetamineinduced stimulation of $c$-fos was abolished by dopamine deafferentation of the host striatum /37/ implying that functional innervation of the transplanted tissue mediated the response. Furthermore, this same study found that the directly acting dopamine receptor agonist, apomorphine, was able to stimulate the expression of fos-like immunoreactivity in the intrastriatal graft following the dopamine deafferentation. Interestingly, apomorphine is able to stimulate the expression of $c$-fos in dopamine deafferented, but not in intact rat striatum. Presumably, this is due to a requirement for supersensitive dopamine receptors for the apomorphine-induced expression of c-fos. Therefore, the data of Mandel et al. /37/ implied that dopamine receptors were present in the transplant and had the same pharmacological characteristics and were under the same regulatory mechanisms as were the receptors in the adult striatum.

Although muscarinic cholinergic receptors develop in fetal striatal grafts this population of receptors may consist of an abnormal ratio of pharmacologically defined receptor subtypes. Deckel et al. $/ 13 /$ reported that the number of putative $M_{1}$ receptors was reduced while the number of putative $\mathrm{M}_{2}$ receptors was increased. This may indicate some abnormality of receptor development which in turn may cause abnormal signal transduction. However, the significance of these findings is unclear as the use of agonist displacement of non-selective muscarinic antagonists can be complex. It was assumed /13/ that the agonist displaceable $\left[{ }^{3} \mathrm{H}\right] \mathrm{N}$-methyl scopolamine (NMS) binding represented a distinct muscarinic receptor subtype $\left(\mathrm{M}_{2}\right)$ while the remaining binding of the $\left[{ }^{3} \mathrm{H}\right] \mathrm{NMS}$ represented the $\mathrm{M}_{1}$ muscarinic receptor. However, the $\mathrm{M}_{1}$ muscarinic receptor subtype has also been demonstrated to have both high and low affinity agonist states $/ 39 /$. Furthermore, the binding of the quaternary antagonist $\left[{ }^{3} \mathrm{H}\right] \mathrm{NMS}$ is complex /41/, making such agonist displacement studies even more difficult to interpret. It is more likely that the ' $\mathrm{M}_{2}$ receptor' represented the high affinity agonist states of a number of muscarinic receptor subtypes rather than a single population of pharmacologically distinct receptors. Conversely, the ' $\mathrm{M}_{1}$ receptor' would represent the low affinity agonist states of these same multiple receptors. The reported changes in agonist competition would indicate that the number of muscarinic receptors in the high affinity agonist state was increased in the transplant relative to the adult host. As the agonist affinity states are determined by coupling to guanine nucleotide regulatory subunits /39/ there may be alterations in cholinergic signal transduction mechanisms in the transplanted tissue.

There was a lack of high affinity choline uptake sites in striatal transplants in spite of the presence of a high density of muscarinic cholinergic receptors, suggesting that few functional cholinergic terminals were present in the transplants $/ 24 /$. Furthermore, the development of alpha-bungarotoxin binding sites in fetal tectum transplanted into rat midbrain occurs independently of inputs from the host brain or functional cholinergic innervation $/ 58 /$. Thus, the functional significance of the muscarinic or putative nicotinic receptors present in the transplants is not clear.

Studies also revealed that some transplant receptor function is conditional and dependent on specific host-transplant anatomical connections and integration. For example, opiate $\kappa$ receptor agonists failed to enhance the stimulation-evoked acetylcholine release in slices of transplants /62/. This effect was observed in normal striatal slices which depended on a dopaminergic input to the 
cholinergic cells. This suggests that opiate $\kappa$ receptor function is dependent not only on the expression of the receptor but also on the integration of the host dopaminergic system with the transplanted tissue. However, it is not clear from these studies whether this dependence of opiate $\kappa$ receptor-mediated responses on dopaminergic innervation reflects the localization of these receptors on dopaminergic fibers as suggested for the opiate $\mu$ receptor $/ 54 /$.

The response of physiologically functional receptors within transplants can be inferred from electrophysiological studies and from the agonistinduced modulation of transmitter release from transplant slices. However, there are also some receptors present in regions of transplants which do not appear to have the appropriate neuronal innervation. Therefore, the functional relevance of these receptors under in vivo conditions is unclear unless they can be activated by neuroactive compounds diffusing from non-local sources.

\section{POSSIBLE FUNCTION OF RECEPTORS IN PROMOTING BEHAVIORAL RECOVERY}

Striatal transplants have been demonstrated to be able to reverse many behavioral deficits induced by striatal excitotoxin lesions $/ 2,16,27,42,51 /$. However, the association between the expression of receptors in transplants and transplant-induced behavioral recovery from lesion-induced deficits is uncertain. For example, it has been reported that the transplant-induced amelioration of apomorphineinduced turning behavior following unilateral excitotoxin lesions of the adult striatum appeared to be independent of the presence of receptors in the transplant $/ 43 /$. Whether or not transplant-derived receptors play a role in behavioral modulation may be dependent on a variety of factors, such as the degree of integration of the receptors with appropriate host circuitry, and/or whether the function mediated via the particular receptors requires local circuits or specific anatomical connections with the host. It is also possible that neurotrophic factors released from transplants may be at least partially responsible for early recovery of drug-induced rotation behavior. The recovery of unilateral excitotoxin lesion-induced rotational behavior was reported as early as 5 weeks following transplantation $/ 40,42,43 /$. At this time, there is no clear evidence for substantial connectivity between host and transplant /59/. Therefore it is possible that trophic factors or other agents may diffuse from the transplant into surrounding host tissue and promote regenerative activity of the remaining host tissue. Indeed, it has been suggested that transplants of adrenal medulla into dopaminergic deafferented rat striatum can induce sprouting of the remaining host dopaminergic fibers, presumably via a trophic mechanism /3/. Trophic factors have also been demonstrated to be produced in the brain in response to injury, and transplants of fetal tissues have been suggested to restore function in part by providing trophic support to the remaining host tissues $/ 5,6 /$. Receptors within the transplant may not be essential for this putative aspect of transplant function. However, for recovery of other motor tasks, for example, skilled paw reaching in rats $/ 16 /$, higher levels of anatomical and functional integration, including receptors, may be required. It has been demonstrated that many transplant-host connections were established in the same patches in which a high density of receptors were present and that were also rich in appropriate neurochemical markers $128 /$. Therefore, it is conceivable that in these areas the receptors in transplants may actively modulate the recovery of more complex host functions.

In addition to host modulation of receptors in the transplanted tissue, neurotransmitter receptors in the host brain can be modulated by transplanted tissue. For instance, intrastriatal ventral mesencephalic transplants were reported to be able to correct dopamine receptor supersensitivity in the striatum following lesion of the nigro-striatal dopaminergic pathway in rats $/ 10,17,46 /$. Interestingly, in the post-mortem striatum of a patient with Parkinson's disease who had received an autologous transplant of adrenal medulla $/ 26,31$, a marked decrease in the levels of 'supersensitive' $\mathrm{D}_{1}$ dopamine receptors was observed returning the receptor levels to those observed in control striatum 131\%. A decrease in the elevated levels of $\mathrm{D}_{2}$ dopamine receptors was also observed in specific regions of the caudate, though the effects were not 
as great as observed for $D_{1}$ dopamine receptors 131\%. This relative normalization of dopamine receptors was restricted to the area immediately surrounding the surviving transplanted cells where there was also an increase in $\left[{ }^{3} \mathrm{H}\right]$ mazindol binding indicating an increased density of dopaminergic terminals. Thus, the localized increase in dopaminergic innervation of the human striatum (possibly due to graft-induced sprouting of remaining host dopaminergic fibers) also appears to elicit changes in levels of dopaminergic receptors in the host striatum.

This relative normalization by fetal transplants of neurotransmitter receptors in the host brain is not restricted to striatum. Cholinergic deafferentation of the rat hippocampus elicits a location-specific increase in muscarinic receptors. Following transplantation of fetal septum into the lesioned hippocampus, an increase in cholinergic markers is observed concomitant with a normalization of the levels of muscarinic receptors $/ 8,29,30,52 /$.

There is also some indirect evidence of fetal tissue transplants modulating receptor sensitivity in the unlesioned rat striatum. Transplantation of various fetal tissues into the intact adult striatum elicited a hyporesponsiveness to most locomotor behaviors induced by amphetamine or by doses of apomorphine which predominantly activate postsynaptic dopamine receptors /35/. Furthermore, the transplanted rats displayed significantly greater catalepsy than normal rats following the injection of the dopamine receptor antagonist haloperidol /35/. These data are consistent with a decreased sensitivity of postsynaptic dopamine receptors. These effects were produced by transplants of different fetal tissues not all of which expressed dopamine receptors $/ 36 /$. This suggested that the transplants produced a common effect in the host striatum. A hypersensitivity to the locomotor inhibiting effects of a lower dose of apomorphine which is relatively selective for autoreceptor activation was observed $/ 35 /$. This suggested that an increase in the sensitivity of presynaptic dopamine receptors could be elicited in the host striatum by transplants. That the transplanted tissue is capable of modulating the function of the host brain in this way demonstrates an important principle of neuroplasticity in adult brain. Clearly transplanted tissues may be capable of inducing many neurochemical and physiological responses in adult host brain. Thus, functional recovery of lesioninduced deficits following neural transplantation might also be produced by transplant-induced receptor plasticity of the adult host brain.

Receptors are key components of signal propagation and also important elements of neuroplasticity $/ 32 /$. Long term changes in the concentration of transmitters may result in changes in the sensitivity of receptor-mediated responses. Transplants of neuronal tissue into host brain will introduce new tissue into the host which may produce a variety of factors, including neurotrophic factors and neurotransmitters. These transplantderived factors may elicit a reorganization of the host tissue. Alternatively, the host may also influence transplant function by modulating its neuronal activity, possibly via changes in receptor sensitivity.

\section{ACKNOWLEDGEMENTS}

Supported by Grant MH45253 from NIMH. We would like to thank Mel Fariello for manuscript preparation.

\section{REFERENCES}

1. Beresford IJ, Hall MD, Clark CR, Hill RG, Hughes J, Sirinathsinghji DJ. Striatal lesions and transplants demonstrate that cholecystokinin receptors are localized on intrinsic striatal neurones: a quantitative autoradiographic study. Neuropeptides $1987 ; 10$ : 109136.

2. Björklund $A$, Lindvall $O$, Isacson $O$, Brundin $P$, Wictorin K, Strecker RE, Clarke DJ, Dunnett SB Mechanisms of action of intracerebral neural implants studies on nigral and striatal grafts to the lesioned striatum. Trends Neurosci 1987; 10: 509-516.

3. Bohn MC, Cupit L, Marciano F, Gash DM. Adrenal medulla grafts enhance recovery of striatal dopaminergic fibers. Science 1987; 237: 913-916

4. Clarke DJ, Dunnett SB, Isacson O, Sirinathsinghji DJS, Björklund A. Striatal grafts in rats with unilateral neostriatal lesions. I. Ultrastructural evidence of afferent synaptic inputs from the host nigrostriatal pathway. Neuroscience 1988; 24: 791-801.

5. Cotman CW, Nieto-Sampedro M. Cell biology of synaptic plasticity. Science $1984 ; 225:$ 1287-1294. 
6. Cotman CW, Kesslak JP. The role of trophic factors in behavioral recovery and integration of transplants. In: Gash DM, Sladek JR Jr., eds, Progress in Brain Research. Amsterdam: Elsevier, 1988; 311-319.

7. Das GD. Neural transplantation in mammalian brain some conceptual and technical considerations. In: Wallace RB, Das GD, eds, Neural Tissue Transplantation Research. New York: SpringerVerlag, 1983; 1-64.

8. Dawson VL, Gage FH, Hunt MA, Wamsley JK. Normalization of subtype-specific muscarinic receptor binding in the denervated hippocampus by septodiagonal band grafts. Exp Neurol 1989; 106: 115124.

9. Dawson TM, Gehlert DR, Wamsley JK. Quantitative autoradiographic localization of central dopamine $\mathrm{D}_{1}$ and $\mathrm{D}_{2}$ receptors. Adv Exp Med Biol 1981; 204: 93118.

10. Dawson TM, Dawson VL, Gage FH, Fisher LJ, Hunt MA, Wamsley JK. Functional recovery of supersensitive dopamine receptors after intrastriatal grafts of fetal substantia nigra. Exp Neurol 1991; 111: 282-292.

11. Deckel AW, Moran TH, Robinson RG. Behavioral recovery following kainic acid lesions and fetal implants of the striatum occurs independent of dopaminergic mechanism. Brain Res 1986; 363: 383385.

12. Deckel AW, Moran TH, Saad K, Robinson RG. Beta adrenoreceptor density in fetal striatal transplants. Eur J Pharmacol 1986; 123: 469-470.

13. Deckel AW, Moran TH, Robinson RG. Receptor characteristics and recovery of function following kainic acid lesions and fetal transplants of the striatum. I. Cholinergic systems. Brain Res 1988; 474 : 27-38.

14. Deckel AW, Moran TH, Robinson RG. Receptor characteristics and recovery of function following kainic acid lesions and fetal transplants of the striatum. II. Dopaminergic systems. Brain Res 1988; 474: 39-47.

15. Dragunow M, Faull R. The use of $\mathrm{c}$-fos as a metabolic marker in neuronal pathway tracing. $J$ Neurosci Meth 1989; 29: 261-264.

16. Dunnett SB, Isacson O, Sirinathsinghji DJS, Clarke DJ, Björklund A. Striatal grafts in rats with unilateral neostriatal lesions, III. Recovery from dopamine dependent motor asymmetry and deficits in skilled paw reaching. Neuroscience 1988; 24: 813-820.

17. Freed WJ. Functional brain tissue transplantation: reversal of lesion-induced rotation by intraventricular substantia nigra and adrenal medulla grafts, with a not eon intracranial retinal grafts. Biol Psychiatry 1983; 18: $1205-1267$

18. Freed WJ, Ko GN, Neihoff DL, Kuhar MJ, Hoffer BJ, Olson L, Cannon-Spoor HE, Morihisa JM, Wyatt RJ. Normalization of spiroperidol binding in the denervated rat striatum by homologous grafts of substantia nigra. Science 1.983; 222: 937-939.

19. Giordano M, Ford LM, Shipley MT, Sanberg PR Neural grafts and pharmacological intervention in a model of Huntington's disease. Brain Res Bull 1990; 25: 453-465.

20. Granholm AE, Palmer MR. Electrophysiological effects of norepinephrine on Purkinje neurons in intraocular cerebellar grafts: alpha- vs beta-specificity. Brain Res 1988; 459: 256-264.

21. Graybiel AM, Ragsdale CW. Biochemical anatomy of the striatum. In: Emson PC, ed, Chemical Neuroanatomy. New York: Raven Press, 1983; 427. 504

22. Graybiel AM, Liu FC, Dunnett SB. Intrastriatal grafts derived from fetal striatal primordia. I. Phenotypy and modular organization. J Neurosci 1989; 9: 3250-3275.

23. Graybiel AM, Moratalla R, Robertson HA. Amphetamine and cocaine induce drug-specific activation of the $c$-fos gene in striosome-matrix compartments and limbic subdivisions of the striatum. Proc Natl Acad Sci USA 1990; 87: 6912-6916

24. Helm GA, Robertson MW, Jallo GI, Simmons N, Bennett JP. Development of $\mathrm{D}_{1}$ and $\mathrm{D}_{2}$ dopamine receptors and associated second messenger systems in fetal striatal transplants. Exp Neurol 1991; 111: 181189.

25. Hoffer BJ, Granholm A, Stevens JO, Olson L Catecholamine-containing grafts in parkinsonism: past and present. Clin Res 1988; 36: 189-195.

26. Hurtig H, Joyce JN, Sladek JR, Trojanowski JQ Postmortem analysis of adrenal-medulla-to-caudate autograft in a patient with Parkinsons disease. Ann Neurol 1989; 25: 607-614

27. Isacson $\mathrm{O}$, Brundin $\mathrm{P}$, Kelly $\mathrm{P}$, Gage $\mathrm{FH}$, Björklund $\mathrm{A}$ Functional neuronal replacement by grafted striatal neurons in the ibotenic acid-lesioned rat striatum. Nature $1984 ; 311$ : 458-460.

28. Isacson $\mathrm{O}$, Dawbarn $\mathrm{D}$, Brundin $\mathrm{P}$, Gage $\mathrm{FH}$, Emson PC, Björklund A. Neural grafting in a rat model of Huntington's disease: striosomal-like organization of striatal grafts as revealed by acetylcholinesterase histochemistry, immunocytochemistry and receptor autoradiography. Neuroscience 1987; 22: 481-497.

29. Joyce JN, Gibbs RB, Cotman CW, Marshall JF Regulation of acetylcholine muscarinic receptors by embryonic septal grafts showing cholinergic innervation of host hippocampus. In: Gash DM, Sladek JR Jr., eds, Progress in Brain Research. Amsterdam: Elsevier, 1988; 109-116.

30. Joyce JN, Gibbs RB, Cotman CW, Marshall JF Regulation of muscarinic receptors in hippocampus following cholinergic denervation and reinnervation by septal and striatal transplants. J Neurosci 1989; 9: 2776-2791.

31. Joyce JN, Hurtig H. Differential regulation of striatal dopamine $D_{1}$ and $D_{2}$ receptor systems in Parkinson's 
disease and effects of adrenal medullary transplant. In: Dunnett SB, Richards SJ, eds, Progress in Brain Research. Amsterdam: Elsevier, 1990; 699-706.

32. Klein WL, Sullivan J, Skorupa A, Aguilar JS. Plasticity of neuronal receptors. FASEB J 1987; 3: 2132-2140.

33. Lanca AJ, Boyd S, Kolb BE, Van Der Kooy D. The development of a patchy organization of the rat striatum. Dev Brain Res 1986; 27: 1-10.

34. Levin BE, Dunn-Meynell A. Noradrenergic innervation does not affect chronic regulation of $\left[{ }^{125}\right.$ I]pindolol receptors in fetal rat brain transplants or host neocortex. Brain Res 1989; 494: 325-338.

35. Lu SY, Giordano M, Norman AB, Shipley MT, Sanberg PR. Behavioral effects of neural transplants into the intact striatum. Pharmacol Biochem Behav 1990; 37: 135-148.

36. Lu SY, Shipley MT, Norman AB, Sanberg PR. Striatal, ventral, mesencephalic and cortical transplants into the intact rat striatum: A neuroanatomical study. Exp Neurol 1991; 113: 109130.

37. Mandel RJ, Wictorin K, Cenci MA, Björklund A. Fos expression in intrastriatal striatal grafts: regulation by host dopaminergic afferents. Brain Res 1992; 583: 207-215.

38. Mayer E, Heavens RP, Sirinathsinghji DJS. Autoradiographic localization of $D_{1}$ and $D_{2}$ dopamine receptors in primordial striatal tissue grafts in rats. Neurosci Lett 1990; 109: 271-276.

39. Norman AB, Battaglia G, Creese I. Regulation of putative muscarinic cholinergic receptor subtypes in rat brain. Neurochem Int 1986; 9: 337-347.

40. Norman AB, Calderon SF, Giordano M, Sanberg PR. Striatal tissue transplants attenuate apomorphineinduced rotational behavior in rats with unilateral kainic acid lesions. Neuropharmacology 1988; 27: 333-336.

41. Norman $A B$, Eubanks $\mathrm{JH}$, Creese I. Irreversible and quaternary muscarinic antagonists discriminate multiple muscarinic receptor binding sites in rat brain J Pharmacol Exp Ther 1989; 248: 1116-1122.

42. Norman $A B$, Lehman $M N$, Sanberg PR. Functional effects of fetal striatal transplants. Brain Res Bull 1989; 22: 163-172.

43. Norman AB, Giordano M, Sanberg PR. Fetal striatal tissue grafts into excitotoxin-lesioned striatum: Pharmacological and behavioral aspects. Pharmacol Biochem Behav 1989; 35: 139-147.

44. Olson L, Backlund EO, Freed W, Herrera MM, Hoffer B, Seiger A, Stromberg I. Transplantation of monoamine-producing cell systems in oculo and intracranially: Experiments in search of a treatment for Parkinsons Disease. Ann NY Acad Sci 1985; 457: 105-126.

45. Pritzel $M$, Isacson $\mathrm{O}$, Brundin $\mathrm{P}$, Wiklund $\mathrm{L}$, Björklund A. Afferent and efferent connections of striatal grafts implanted into the ibotenic acid lesioned neostriatum in adult rats. Exp Brain Res 1986; 65: 112-126.

46. Rioux L, Gaudin DP, Gagnon C, DiPaolo T, Bedard PJ. Decrease of behavioral and biochemical denervation supersensitivity of rat striatum by nigral transplants. Neuroscience 1991; 44: 75-83.

47. Robertson HA, Peterson MR, Murphy K, Robertson GS. $D_{1}$-dopamine receptor agonists selectively activate striatal $c$-fos independent of rotational behaviour. Brain Res 1989; 503: 346-349.

48. Rutherford A, Garcia-Munoz M, Dunnett SB Arbuthnott, GW. Electrophysiological demonstration of host cortical inputs to striatal grafts. Neurosci Lett 1987; 83: 275-281.

49. Sanberg PR, Henault MA, Deckel AM. Locomotor hyperactivity effects of multiple striatal transplants in an animal model of Huntington's disease. Pharmacol Biochem Behav 1986; 25: 297-300.

50. Sanberg PR, Henault MA, Hagenmeyer-Houser SH, Giordano M, Russell KH. Multiple transplants of fetal striatal tissue in the kainic acid model of Huntingtons disease: Behavioral recovery may not be related to acetylcholinesterase. In: Azmitia EC, Björklund A, eds, Cell and Tissue Transplantation into the Adult Brain. Ann NY Acad Sci 1987; 781-785.

51. Sanberg PR, Calderon SF, Garver DL, Norman AB. Brain tissue transplants in an animal model of Huntingtons disease. Psychopharmacol Bull 1987; 23: 476-482

52. Segal M, Greenberger V, Pearl E. Septal transplants ameliorate spatial deficits and restore cholinergic functions in rats with a damaged septo-hippocampal connection. Brain Res 1989; 500: 139-148.

53. Sirinathsinghji DJS, Dunnett SB, Isacson O, Clarke DJ, Kendrick K, Björklund A. Striatal grafts in rats with unilateral neostriatal lesions - II. In vivo monitoring of GABA release in globus pallidus and substatia nigra. Neuroscience 1988; 24: 803-811.

54. Sirinathsinghji DJS, Dunnett SB. Disappearance of the $\mu$-opiate receptor patches in the rat neostriatum following lesioning of the ipsilateral nigrostriatal dopamine pathway with 1-methyl-4-phenylpyridinium ion $\left(\mathrm{MPP}^{+}\right)$: restoration by embryonic nigral dopamine grafts. Brain Res 1989; 504: 115-120.

55. Sladek JR, Gash DM. Nerve-cell grafting in Parkinsons disease. J Neurosurg 1988; 68: 337-351.

56. Spiegel AM, Downs RW. Guanine nucleotides: key regulators of hormone receptor-adenylate cyclase interaction. Endocr Rev 1981; 2: 275-305.

57. Strecker RE, Sharp $T$, Brundin $P$, Zetterstrom $T$, Ungerstedt $U$, Björklund A. Autoregulation of dopamine release and metabolism by intrastriatal nigral grafts as revealed by intracerebral dialysis. Neuroscience 1987; 22: 169-178. 
58. Tan MML, Harvey AR. The development and distribution of alpha-bungarotoxin binding sites in rat tectal transplants. Dev Brain Res 1987; 36: 293-298.

59. Walker PD, McAllister JP. Minimal connectivity between neostriatal transplants and the host brain. Brain Res 1987; 425: 34-44.

60. Walker PD, Chovanes GI, McAllister JP. II Identification of acetylcholinesterase-reactive neurons and neuropil in neostriatal transplants. J Comp Neurol 1987; 295: 1-12.

61. Walsh JP, Zhou FC, Hull CD, Fisher RS, Levine MS, Buchwald NA. Physiological and morphological characterization of striatal neurons transplanted into the striatum of adult rats. Synpase 1988; 2: 34-44.

62. Wichmann T, Starke K. Modulation by muscarine and opioid receptors of acetylcholine release in slices from striato-striatal grafts in the rat. Brain Res 1990; 510: 296-302.
63. Wictorin $\mathrm{K}$, Isacson $\mathrm{O}$, Fischer $\mathrm{W}$, Nothias $\mathrm{F}$, Peschanski M, Björklund A. Connectivity of striatal grafts implanted into the ibotenic acid-lesioned striatum. I Subcortical afferents. Neuroscience 1988; 27: $547-562$.

64. Wictorin K, Björklund A. Connectivity of striatal grafts implanted into the ibotenic acid-lesioned striatum. II Cortical afferents. Neuroscience 1989; 30: 297-311.

65. Wictorin K, Simley RB, Isacson O, Swanson LW, Björklund A. Connectivity of striatal grafts implanted into the ibotenic acid-lesioned striatum. III Efferent projecting graft neurons and their relation to afferents within the grafts. Neuroscience $1989 ; 30: 313-330$.

66. Zhou FC, Buchwald N, Hull C, Towle A. Neuronal and glial elements of fetal neostriatal grafts in the adult neostriatum. Neuroscience 1989; 30: 19-31. 

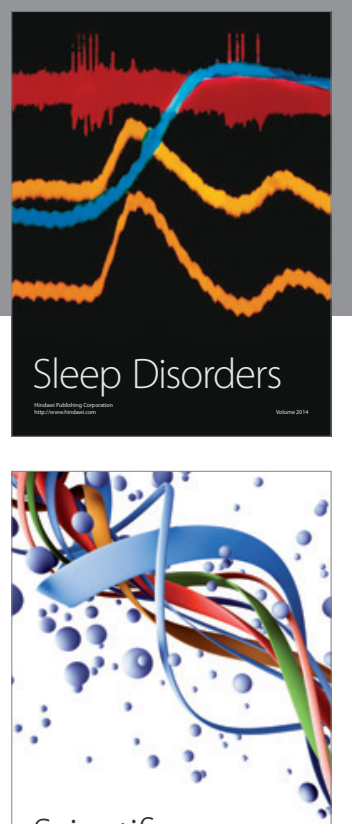

Scientifica
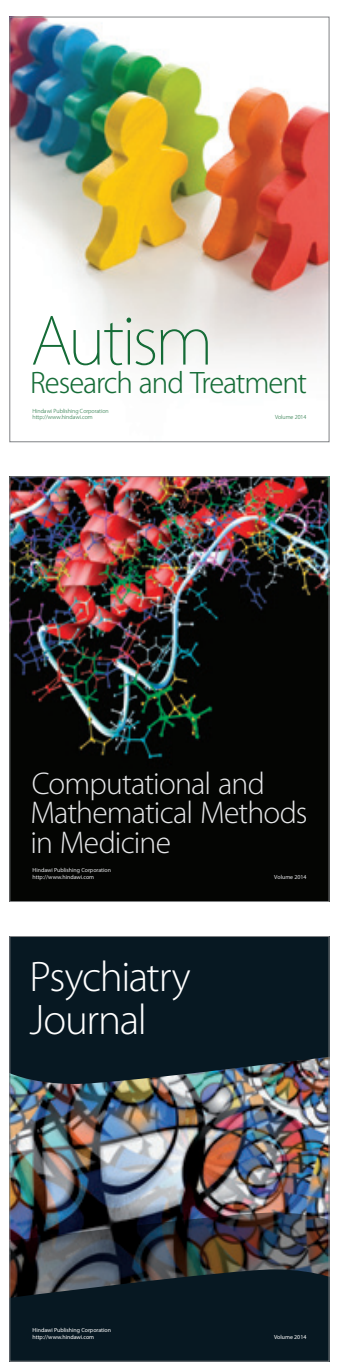
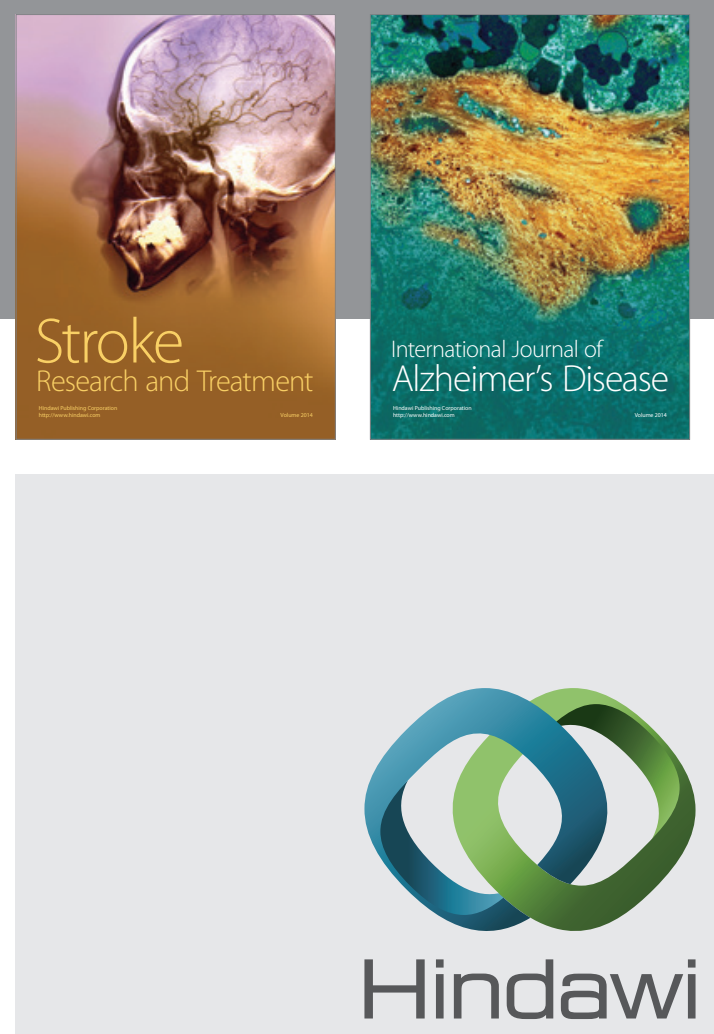

Submit your manuscripts at

http://www.hindawi.com
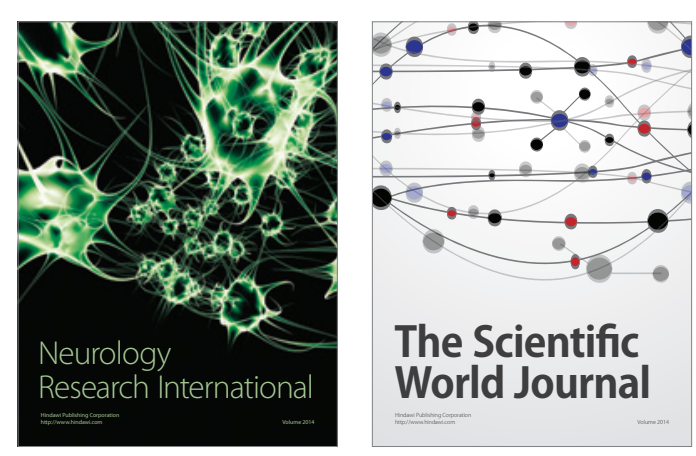

The Scientific World Journal

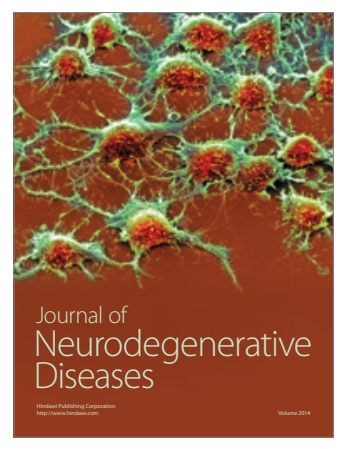

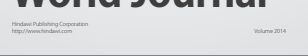

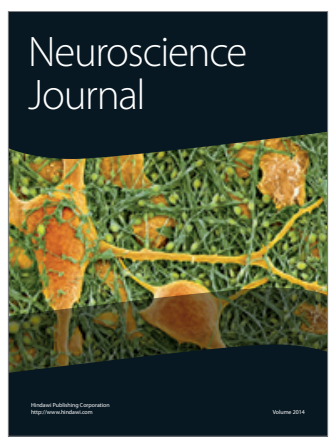

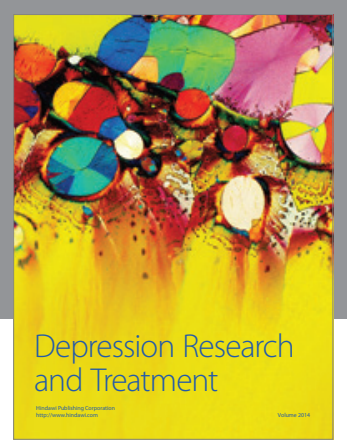
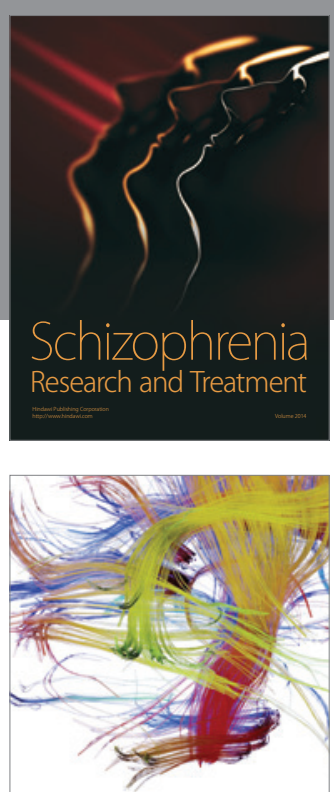

Brain Science

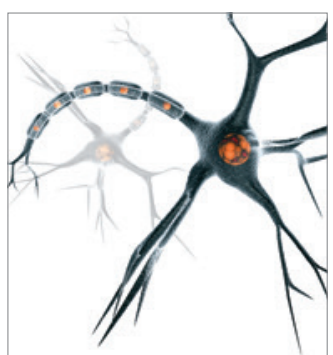

Neural Plasticity
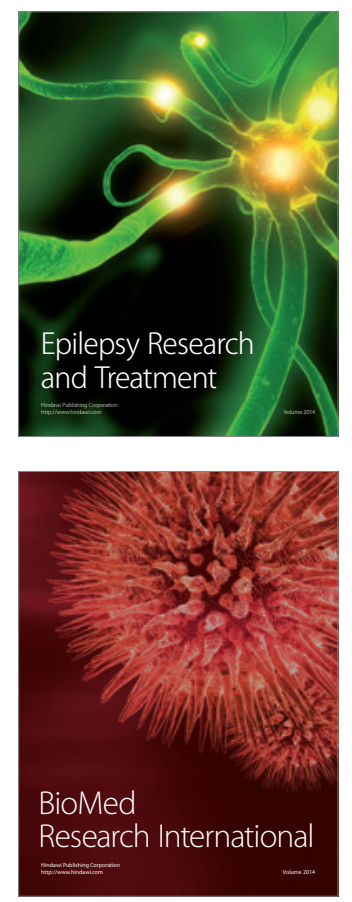

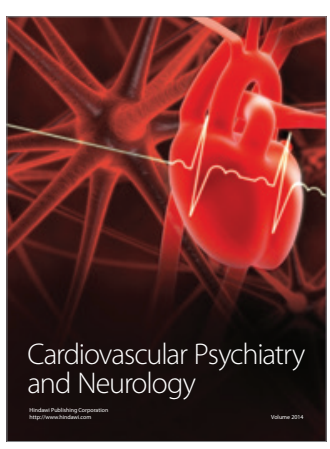

Parkinson's

Disease
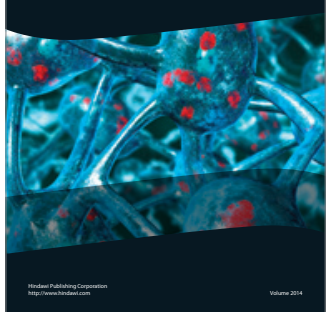